\title{
Intellectual Capital Performance of Pakistani Listed Corporate Sector
}

\author{
M. A. Majid Makki (Corresponding author) \\ Department of Commerce, the Islamia University of Bahawalpur, Pakistan \\ Tel: 92-42-5162633Ｅ-mail: abdul7896@yahoo.com.au
}

Suleman Aziz Lodhi

National College of Business Administration \& Economics, Lahore, Pakistan

E-mail: sulemanlodhi@yahoo.com

Rashid Rahman

Department of Business Administration, Gomal University, D.I. Khan, Pakistan

E-mail: drrashid.rehman@gmail.com

\begin{abstract}
Performance of Intellectual Capital (IC) in an enterprise is becoming a critical success factor. The paper measures, evaluates and ranks the IC performance of the second largest stock exchange of Pakistan, the Lahore Stock Exchange index companies (LSE-25). It uses popular IC model, Value Added Intellectual Coefficient (VAIC ${ }^{\mathrm{TM}}$ ) developed by Ante Pulic in 1998. Six-year data of LSE-25 was obtained from audited financial reports to calculate human capital, structural capital and capital employed efficiency of companies related to different industrial sectors. Findings indicate that oil \& gas, chemical and cement sectors show top performance; banking sector shows average performance; and public sector companies show least performance. The study is a pioneering attempt to measure the IC performance in Pakistan using cross sectional data.
\end{abstract}

Keywords: Intellectual capital efficiency, Human capital, Structural capital, Value Added Intellectual Coefficient $\left(\mathrm{VAIC}^{\mathrm{TM}}\right)$

\section{Introduction}

The existing corporate performance measurement system is heavily inclined towards financial and physical aspects and lacks the relevant information on intellectual capital efficiency. Consequently, many companies are satisfied with their financial performance, while the reality is different, as they face declining IC efficiency. Therefore new tools are needed for measuring the performance of enterprises in addition to financial performance. An appropriate tool is to measure and rank the companies according to their IC performance. Johnson and Kaplan (1987) emphasize that IC plays very important role in overall performance of an enterprise. Bornemann (1999) explored positive correlation between intellectual potential and economic performance. According to Pulic (2000a), IC is a moving force for business success.

At macro level, the importance of IC performance is increasing as nations move towards Knowledge-Economy. Malaysian economists accept that to maintain the pace of economic development it is inevitable to transform the production-based economy to knowledge-based economy. The Knowledge Economy Master Plan of Malaysia published in 2001, consists of strategies to transform Malaysia from an input driven economy to a knowledge driven economy. The vital role of knowledge is also emphasized in World Development Report (1998) asserting that today's most technologically advanced economies are truly knowledge based. Malaysian researchers, Naquiyuddin and Heong (1992) explain, knowledge is an essential and can be used as a strategic tool against competitors. In a situation when world is moving towards knowledge economy, many corporate managers feel that Pakistan is loosing its strong markets to traditional competitors i.e. China, India and Bangla-Desh due to its lesser knowledge capital efficiency. As Kalim and Lodhi (2002) emphasize that Pakistan must take drastic steps to make its industry more knowledge efficient; otherwise Pakistan may lose even its present share of world exports.

IC is a strategic intangible asset which can transform a national firm to multinational and transnational corporate powerhouse. The research objective is to rank LSE-25 companies according to their IC performance, and identify best performers. IC performance measurement and management have become more important when service sectors are 
playing vital role in growth of economies around the globe and their share in overall GDP is rising rapidly than production sector.

\section{Literature review}

Generally, IC is defined as creative abilities of human brain or mind. Edvinson and Malone (1997) defined IC as knowledge that can be converted into value. They further explain difference of market value and book value as value of IC. Stewart (1997) viewed IC as knowledge, information, intellectual property and expertise that can be put to use to create wealth. While Bontis et.al. (2000) explain IC as individual workers' and organizational knowledge that contribute to sustainable competitive advantage. He further elaborates that IC in broad sense consists of human capital and structural capital. While Pulic (2000a) includes all employees and their abilities that create value addition. Moore (1996) defines IC as customer capital, innovation capital and organizational capital. On the other side of the fence, Blair and Wallman (2001) perceive that it is difficult to provide precise definition for intangible assets as well as IC.

IC concepts can be categorized into, two major schools of thought (Mavridis, 2004). First school focuses on cost and tries to compute the IC through the difference between market and book value. Second school of thought is value oriented and focuses to measure IC efficiency through value addition by human and structural capital. Approach of second school of thought seems to be more recognized in the world. As method (VAIC ${ }^{\mathrm{TM}}$ ) related to this school of thought based on value addition has been assessed and used by more than 12 researchers from different countries. VAIC $^{\mathrm{TM}}$ approach is placed in second school of thought and it has become very popular. Its strength lay in its straightforward calculations, availability of reliable audited data and easy in comparison across various industrial sectors (Pulic, 2004). Alternative IC measures are limited as they can only be calculated by internal parties or they rely on sophisticated models, analysis and principles (Pulic, 2004). Beside the above Sveiby (1997) proposes conceptual framework for IC based on external structure (brands, customer and supplier relations); internal structure (organization, structure, system corporate attitude, R\&D and procedures); and individual competence (education, experience) argues that money must not be used as proxy for human efforts.

In the developed world, the research in IC domain is widely explored by researchers; however there have been too few studies that have focused emerging economies as case for evaluating the implications of IC at stock exchange level. Pulic (2000b) used VAIC ${ }^{\mathrm{TM}}$ to measure and analyze the performance of FTSE-250 companies of London Stock Exchange. Kujansivu (2006) utilized subordinate concept of VAIC ${ }^{\mathrm{TM}}$, intellectual capital efficiency (ICE) to analyze the IC performance of 20,000 companies covering 11 largest industries of Finland. Some other studies related to IC disclosure of FTSE-100, S\&P-500 companies were conducted by William (2001) and Robert (2000) respectively. Mavridis (2004), Goh (2005) and Kamath (2007) used VAIC ${ }^{\mathrm{TM}}$ to analyze the performance of Japanese, Malaysian and Indian banks respectively and found significant differences in IC performance among the banks. Mavridis (2005) once more used VAIC ${ }^{\mathrm{TM}}$ and its subordinate concept best performance index (BPI) to analyze the performance of Greek banking sector and focused on the role of human capital (HC) and physical capital (CA) in value addition. Kamath (2007a) once again used VAIC ${ }^{\mathrm{TM}}$ methodology to measure and evaluate the IC performance of Indian pharmaceutical industry.

\section{Methodology}

The Value Added Intellectual Coefficient $\left(\mathrm{VAIC}^{\mathrm{TM}}\right)$ used in this paper as a basic methodology to calculate and analyze the IC performance of LSE-25 companies was introduced by Pulic (1998). It gives a new insight to measure value creation efficiency in companies using data available in financial statements. VAIC ${ }^{\mathrm{TM}}$ is designed to effectively evaluate the efficiency in adding value (VA) by a firm. It focuses on value addition in an organization and not on cost control (Pulic, 2000a). The core concept of VAIC ${ }^{\mathrm{TM}}$ is that the human capital is mainly responsible for overall performance of the firm. VAIC ${ }^{\mathrm{TM}}$ is based on the following five calculations:

(i) $\mathrm{VA}=$ OUT $-\mathrm{IN}$

Where VA is the value addition from current year resources.

Out $=$ Total Sales and

In $=$ Cost of bought in materials, components and services

Alternatively value added can be calculated as $\mathrm{VA}=\mathrm{OP}+\mathrm{EC}+\mathrm{D}+\mathrm{A}$

Where OP $=$ Operating Profit $\quad \mathrm{EC}=$ Employee Cost

$\mathrm{D}=$ Depreciation $\quad \mathrm{A}=$ Amortization

(ii ) $\mathrm{VACA}=\mathrm{VA} / \mathrm{CA}$

Where VACA is the capital employed efficiency of the firm and

$\mathrm{CA}=$ Capital Employed (net book value of total assets) 
(iii) $\mathrm{VAHU}=\mathrm{VA} / \mathrm{HC}$

Where VAHU is the human capital efficiency of the firm and

$\mathrm{HC}=$ Total salaries and wages (Direct labour + Indirect

labour + Admn., Marketing and Selling salaries)

( iv ) $\mathrm{STVA}=\mathrm{ST} / \mathrm{VA}$

Where STVA is the structural capital efficiency of the firm and

$$
\begin{gathered}
\mathrm{ST}=\mathrm{VA}-\mathrm{HC} \\
\text { (v) } \mathrm{VAIC}^{\mathrm{TM}}=\mathrm{VACA}+\mathrm{VAHU}+\mathrm{STVA}
\end{gathered}
$$

Where VAIC indicates the corporate value creation efficiency

It must be noted that $\mathrm{VAIC}^{\mathrm{TM}}$ does not provide money value of IC. It simply adds the 3 different efficiency factors of IC and calculates efficiency index that shows how IC of a company contributes towards value addition. Measuring IC efficiency, Pulic (2000a) also offers VAIC's subordinate concept that adds human and structural capital efficiency (ICE=VAHU+STVA).

\section{Description, analysis and results}

Major objective of the study is to examine and evaluate the IC performance of LSE-25 companies for six-year period from 2002 to 2007. The data was collected from six years audited financial statements of relevant companies. Evaluation is done on the basis of ranking based on VAIC ${ }^{\mathrm{TM}}$ index and its subordinate concept ICE of each firm. The description of data aims towards better understanding of the values on the basis of which IC efficiency of firms is to be measured. Companies in the study are not limited to particular industrial sector, so as to see overall IC performance of top 25 companies of Lahore Stock Exchange.

Sector wise profile of LSE-25 index given in Table I is based on trading-volume wise top 25 companies of Lahore Stock Exchange having total market capitalization of Rs.1,719,754,463,599/= on $31^{\text {st }}$ January, 2007 (LSE Newsletter, 2007).

Table II illustrates mean, minimum, maximum and standard deviation for different dependent and independent variables. The mean of human capital efficiency is 6.54 with minimum efficiency of -3.22 to maximum 21.93 . That means LSE-25 companies produced Rs.6.54 on average for every one rupee spent on human capital. While, average VAIC $^{\mathrm{TM}}$ and ICE remained 7.60 and 7.29 respectively.

An evident aspect of Table III is that cement, oil \& gas and chemical sectors are the top performers. Although 7 banks were represented in the sample, but none of them falls in the top ten performers as per 2006 results. Even then, their performance is good according to the performance zones computed in the study of 'IC performance of Japanese banking sector (Mavridis, 2004). In the banking sector, Faysal Bank Ltd. (a foreign financial institution) remains on the top both in VAIC ${ }^{\mathrm{TM}}$ and ICE results in 2006. The reason behind high IC performance by Faysal Bank could be due to lesser investment in $\mathrm{HC}$, more focus on big corporate clients and high value financial products. Results are consistent with the findings of the study of 'IC Performance of Indian Banks' (Kamath, 2007). She describes score of 5.0 or above for top performer banks and below 2.50 for bad performers. While, Goh (2005) works out 7.91 as average VAIC ${ }^{\mathrm{TM}}$ for Malaysian banks. It can be concluded that in relation to Indian and Japanese performance zones, IC performance of Pakistani banks is quite satisfactory and if Malaysian banks are benchmarked then their performance would be considered poor.

Based on the 6 year figures for VAIC and ICE, changes in efficiency level of each company over the time can be assessed from Table III and Table IV. Large differences are found among top performers, least performers and different industrial sectors in value creation efficiency. ICE index ranking shows almost the same results, oil \& gas, cement and chemical sectors have been found the best performers again. Most of the VAIC ${ }^{\mathrm{TM}}$ top performers are also excellent in ICE. Top performance of oil and gas sector in VAIC ${ }^{\mathrm{TM}}$ and ICE rankings is consistent with Kujansivu,s (2006) study of IC performance of Finnish companies. Public sector Pakistan International Airlines (PIA) and Pakistan Cement Ltd. were found least performers again. As far as least IC performance of Pakistan Cement is concerned, it has not yet started its commercial production. But more than 50 year old corporation PIA shows a consistently deteriorating trend in IC efficiency, which could be due to underutilization of its huge workforce, low productivity and outdated technology. PICIC and Bank Al-Falah also show declining trend in their IC performance, which could be due to huge non-performing loans, unplanned growth and poor investment decisions. These results were found consistent with IC performance of Indian banks (Kamath, 2007).

\section{Conclusion and policy implications}

After evaluating the IC performance of LSE-25 based on VAIC ${ }^{\mathrm{TM}}$ and ICE it is clear that best performing companies are those who mainly have good results in using human capital. This indicates that knowledge workers strongly 
contribute towards value addition. Demand for IC disclosure has reached to top-ten information needs by users of financial statements in U.K. (Taylor Associates, 1998). But our conventional accounting system does not include IC disclosure in financial statements resulting trillions of value remains unrecorded. Even in a situation of least disclosure of IC in annual reports as well as non-recognition of IC by conventional accounting system, investors give value to invisible IC. So, IC efficiency and its disclosure should be considered as strategic asset for sustainable comparative advantage of a firm in a knowledge economy. International Accounting Standard Board and Securities \& Exchange Commission of Pakistan may consider to establish accounting standard on IC like IAS-38 (Accounting for Intangibles) to record the intellectual assets at true $\&$ fair value and to disclose an important information need for users of financial statements.

\subsection{Usefulness of the study}

Being a pioneering attempt to analyze the performance of LSE-25 from a different perspective of IC, this paper would be a good source of reference for future research in Pakistani corporate sector. ICE can be used by fund manager for evaluating the performance of firms to visualize the improved picture before investment decision. The findings have implications for shareholders, potential investors and management to assess below par IC performance of their firm. This study can be used as benchmark for cement and banking sectors while evaluating their IC performance. VAIC ${ }^{\mathrm{TM}}$ based analysis are also useful to identify the problems and strength of different industrial sectors.

\section{References}

Blair, M.M. and Wallman, S.M.H. (2001). Unseen Wealth: Report of the Brooking's Task Force on Intangibles. Brookings Institute Press, Washington, D.C.

Bontis, N. (1998). Intellectual Capital: an exploratory study that develops measures and Models. Management Decisions, 36, 2, 63-76.

Bontis, N., Kew, W.C.C. and Richardson, S. (2000). Intellectual Capital and Business Performance in Malaysian Industries. Journal of Intellectual Capital, 1, 1, 85-100.

Bornemann, M. (1999). Potential of Value Systems According to the VAIC ${ }^{\mathrm{TM}}$ Method. International Journal Technology Management, 18, 5, 463-475.

Edvinson, L. and Malone, M. (1997). Intellectual Capital: Realizing your company's true value by finding its hidden brain power, Harper Business, New York.

Goh, P.C. (2005). Intellectual Capital Performance of Commercial Banks in Malaysia. Journal of Intellectual Capital, 6, 3, 385-396.

Johnson, H. T., Kaplan, R. S. (1987). Relevance Lost: The Rise and Fall of Management Accounting, Harvard Business School Press, Boston.

Kalim R and Lodhi, S. A. (2002). The Knowledge Based Economy: Trends and Implications for Pakistan. Pakistan Development Review, 41, 4, Part II, 787-804.

Kamath, G.B. (2007). The Intellectual Capital Performance of Indian Banking Sector. Journal of Intellectual Capital, 8 , $1,96-123$.

Kamath, G.B. (2007a). Value Added by Intellectual Capital: A Study of the Indian Pharmaceutical Industry. The Icfai Journal of Knowledge Management, 5, 5, 57-68.

Kujansivu, P. (2006). Intellectual Capital Performance in Finnish Companies, paper presented in $3^{\text {rd }}$ Conference on Performance and Management Control, Nice, Finland.

LSE Newsletter (2007). Lahore Stock Exchange. February, 2007, pp. 3-4.

Mavridis, D.G. (2004). The Intellectual Capital Performance of Japanese Banking Sector. Journal of Intellectual Capital, 5, 1, 92-114.

Mavridis, D.G (2005). Intellectual Capital Performance Drivers in the Greek Banking Sector. Management Research News, 28, 5, 43-62.

Moore, N.G. (1996). Measuring Corporate IQ. Chief Executive, November, 1996.

Naquiyuddin, T.N.C.P. and Heong, L.H. (1992). Malaysian Entrepreneurs, Malaysian Institute of Management, Kuala Lumpur.

Pulic, A. (1998). Measuring the Performance of Intellectual Potential in Knowledge Economy.[Online] Available: www.vaic-on.net (March 16, 2008).

Pulic, A. (2000a).VAIC ${ }^{\mathrm{TM}}$ - an Accounting Tool for IC Management. [Online] Available: www.vaic-on.net (March 16, 2008). 
Pulic, A. (2000b). MVA and VAIC ${ }^{\mathrm{TM}}$ Analysis of Randomly Selected Companies from FTSE-250. Austrian IC Research Center, Graz-London.

Pulic, A. (2004). Intellectual Capital - does it create or destroy value? Measuring Business Excellence, 8, 1, 62-68.

Robert, E. (2000). Corporate Disclosure in the Internet Age. The Financial Times, $14^{\text {th }}$ May, 2000

Stewart, T.A. (1997). Intellectual Capital: The New Wealth of Organizations, Doubleday, New York, N.Y.

Sveiby, K.E. (1997). The New Organizational Wealth:Managing and Measuring Knowledge based Assets, BarrettKohler, San Francisco.

Taylor and Associates (1998). Full Disclosure, Shelly Taylor, London.

William, S.M. (2001). Is a Company's Intellectual Capital Performance and Intellectual Capital Disclosure Practices Related?, Evidence from Publicly Traded Companies from FTSE-100. [Online] Available: www.vaic-on.net (March 16, 2007).

World Bank (1998), World Development Report. [Online] Available at: www.worldbank.org

Table 1. Sector wise profile of LSE-25 (2006)

\begin{tabular}{|l|c|c|c|}
\hline Sector & Firms & Years & Firm-years \\
\hline Banks & 7 & 6 & 42 \\
\hline Oil/Gas/Power & 7 & 6 & 42 \\
\hline Cement & 5 & 6 & 30 \\
\hline Chemical/Fertilizer & 2 & 6 & 12 \\
\hline Others & 4 & 6 & 24 \\
\hline Total & 25 & & 150 \\
\hline
\end{tabular}

Table 2. Descriptive Statistics of selected variables for the year 2007 of LSE-25

\begin{tabular}{|l|r|r|r|r|r|}
\hline Variables & \multicolumn{1}{|c|}{ N } & Minimum & Maximum & \multicolumn{1}{l|}{ Mean } & \multicolumn{1}{l|}{ S.D } \\
\hline VALUE ADDED (Rs. in Millions) & 25 & -39 & 70 & 12 & 17 \\
\hline HUMAN CAPITAL (Rs. in Millions) & 25 & 12 & 14700 & 2726 & 611 \\
\hline CAPITAL EMPLOYED (Rs. in Millions) & 25 & 4248 & 158840 & 39420 & 734 \\
\hline STRUCTURAL CAPITAL (Rs. in Millions) & 25 & -5097 & 67384 & 10248 & 516 \\
\hline CAPITAL EMPOYED EFFICIENCY & 25 & -0.0027 & 0.7450 & 0.3081 & 0.2097 \\
\hline HUMAN CAPITAL EFFICIENCY & 25 & -3.2221 & 21.9286 & 6.5368 & 5.1534 \\
\hline STRUCTURAL CAPITAL EFFICIENCY & 25 & -0.9591 & 1.3104 & 0.7559 & 0.3847 \\
\hline NET PROFIT (Rs. in Millions) & & -12763 & 45970 & 5228 & 10733 \\
\hline EPS (Rs.) & 25 & -6.80 & 43.90 & 8.21 & 10.66 \\
\hline ICE & 25 & -1.9117 & 22.8829 & 7.2927 & 5.2865 \\
\hline VAIC ${ }^{\text {TM }}$ & 25 & -1.9144 & 23.6279 & 7.6008 & 5.3994 \\
\hline
\end{tabular}


Table 3. VAIC ${ }^{\mathrm{TM}}$ Ranking of LSE-25 (Sorted based on 2007 results)

\begin{tabular}{|c|c|c|c|c|c|c|c|}
\hline & \multicolumn{7}{|c|}{$\mathrm{VAIC}^{\mathrm{TM}}=\mathrm{VACA}+\mathrm{VAHU}+\mathrm{STVA}$} \\
\hline & Company Name & VAIC-2007 & VAIC-2006 & VAIC-2005 & VAIC-2004 & VAIC-2003 & VAIC-2002 \\
\hline 1 & $\begin{array}{l}\text { Oil and Gas Dev. } \\
\text { Corp. Ltd. }\end{array}$ & 20.76 & 23.63 & 22.55 & 14.97 & 14.62 & 12.57 \\
\hline 2 & Pak Petroleum Ltd. & 12.25 & 12.45 & 10.04 & 8.86 & 5.26 & 4.57 \\
\hline 3 & Lucky Cement Ltd. & 9.32 & 11.44 & 10.45 & 10.34 & 6.75 & 6.71 \\
\hline 4 & Pakistan PTA Ltd. & 9.26 & 10.92 & 14.65 & 13.79 & 9.35 & 11.43 \\
\hline 5 & $\begin{array}{l}\text { D.G.Khan Cement } \\
\text { Co. Ltd. }\end{array}$ & 9.19 & 16.55 & 14.00 & 10.02 & 6.77 & 8.64 \\
\hline 6 & $\begin{array}{l}\text { Fauji Fetilizer Bin } \\
\text { Qasim Ltd. }\end{array}$ & 8.64 & 9.56 & 10.19 & 9.99 & 6.55 & 6.18 \\
\hline 7 & Fauji Cement Co. Ltd. & 8.07 & 14.02 & 12.56 & 15.75 & 8.30 & 7.41 \\
\hline 8 & Pak State Oil Co. Ltd. & 6.83 & 9.09 & 7.83 & 7.02 & 7.27 & 8.02 \\
\hline 9 & MCB Bank Ltd. & 5.45 & 5.54 & 4.51 & 2.92 & 2.62 & 2.28 \\
\hline 10 & Nishat Mills Ltd. & 5.43 & 4.14 & 5.18 & 3.71 & 3.82 & 4.12 \\
\hline 11 & $\begin{array}{l}\text { The Bank of Punjab } \\
\text { Ltd. }\end{array}$ & 5.41 & 6.42 & 6.14 & 4.26 & 3.26 & 2.25 \\
\hline 12 & National Bank of Pak & 4.88 & 5.23 & 4.99 & 3.92 & 3.60 & 3.31 \\
\hline 13 & $\begin{array}{l}\text { Askari Comm. Bank } \\
\text { Ltd. }\end{array}$ & 4.54 & 5.17 & 5.21 & 6.09 & 5.90 & 5.45 \\
\hline 14 & $\begin{array}{l}\text { Sui Nor. Gas Pipeline } \\
\text { Ltd. }\end{array}$ & 4.41 & 4.38 & 4.43 & 3.16 & 4.26 & 4.20 \\
\hline 15 & $\begin{array}{l}\text { Dewan Salman Fibre } \\
\text { Ltd. }\end{array}$ & 4.36 & 5.38 & 5.59 & 6.91 & 6.47 & 9.44 \\
\hline 16 & $\begin{array}{l}\text { Pak Telecom Corp. } \\
\text { Ltd. }\end{array}$ & 4.35 & 4.84 & 5.86 & 7.67 & 7.24 & 7.11 \\
\hline 17 & $\begin{array}{l}\text { Pakistan Cement Co. } \\
\text { Ltd. }\end{array}$ & 4.09 & -1.91 & -2.91 & 0.58 & 1.18 & 1.19 \\
\hline 18 & $\begin{array}{l}\text { Maple Leaf Cement } \\
\text { Fact. Ltd. }\end{array}$ & 3.88 & 10.06 & 10.17 & 10.54 & 6.63 & 9.45 \\
\hline 19 & $\begin{array}{l}\text { Sui Southern Gas Co. } \\
\text { Ltd. }\end{array}$ & 3.82 & 3.65 & 3.40 & 3.32 & 3.67 & 3.88 \\
\hline 20 & Faysal Bank Ltd. & 3.74 & 7.15 & 7.33 & 6.70 & 9.39 & 5.42 \\
\hline 21 & Bank Alfalah Ltd. & 3.20 & 3.21 & 3.83 & 6.58 & 7.02 & 4.03 \\
\hline 22 & $\begin{array}{l}\text { Karachi Elect. Corpl } \\
\text { Ltd. }\end{array}$ & 2.28 & 6.86 & 6.14 & 1.77 & -1.54 & -0.19 \\
\hline 23 & PIA Corp (A) & 0.85 & -0.36 & 0.41 & 2.32 & 3.09 & 4.68 \\
\hline 24 & Bosicor Pakistan Ltd. & 0.42 & 9.04 & 9.47 & -9.12 & 0.63 & 5.61 \\
\hline 25 & $\begin{array}{l}\text { PICIC Bank Ltd/NIB } \\
\text { Bank }\end{array}$ & 0.15 & 3.55 & 9.88 & 11.02 & 6.64 & 3.92 \\
\hline
\end{tabular}

* Data is not publicly available due to non-listing status of the company in this year. 
Table 4. Intellectual Capital Efficiency $\left(\mathrm{ICE}^{\mathrm{TM}}\right.$ ) Ranking of LSE-25 (Sorted based on 2007 results)

\begin{tabular}{|c|c|c|c|c|c|c|c|}
\hline & \multicolumn{7}{|c|}{ ICE $=$ VAHU + STVA } \\
\hline & Company Name & $\begin{array}{l}\text { ICE - } \\
2007\end{array}$ & $\begin{array}{l}\text { ICE - } \\
2006\end{array}$ & $\begin{array}{l}\text { ICE - } \\
2005\end{array}$ & $\begin{array}{l}\text { ICE } \\
-2004\end{array}$ & $\begin{array}{l}\text { ICE } \\
-2003\end{array}$ & $\begin{array}{l}\text { ICE } \\
-2002\end{array}$ \\
\hline 1 & Oil and Gas Dev. Corp. Ltd. & 20.18 & 22.88 & 21.89 & 14.46 & 14.14 & 11.76 \\
\hline 2 & Pak Petroleum Ltd. & 11.62 & 11.73 & 9.35 & 8.18 & 4.69 & 3.97 \\
\hline 3 & D.G.Khan Cement Co. Ltd. & 9.12 & 16.38 & 13.79 & 9.82 & 6.64 & 8.47 \\
\hline 4 & Lucky Cement Ltd. & 9.09 & 11.28 & 10.32 & 10.11 & 6.57 & 6.56 \\
\hline 5 & Pakistan PTA Ltd. & 8.99 & 10.45 & 14.12 & 13.30 & 9.08 & 11.27 \\
\hline 6 & Fauji Fetilizer Bin Qasim Ltd. & 8.31 & 9.31 & 9.94 & 9.78 & 6.45 & 6.08 \\
\hline 7 & Fauji Cement Co. Ltd. & 7.79 & 13.51 & 12.29 & 15.42 & 8.19 & 7.29 \\
\hline 8 & Pak State Oil Co. Ltd. & 6.35 & 8.46 & 7.20 & 6.49 & 6.70 & 7.49 \\
\hline 9 & The Bank of Punjab Ltd. & 5.38 & 6.38 & 6.10 & 4.26 & 3.22 & 2.21 \\
\hline 10 & MCB Bank Ltd. & 5.37 & 5.13 & 4.10 & 2.46 & 2.41 & 1.97 \\
\hline 11 & Nishat Mills Ltd. & 5.29 & 3.98 & 4.97 & 3.45 & 3.51 & 3.69 \\
\hline 12 & National Bank of Pak & 4.82 & 4.67 & 4.40 & 3.60 & 3.34 & 3.10 \\
\hline 13 & Askari Comm. Bank Ltd. & 4.48 & 4.94 & 4.98 & 5.89 & 5.76 & 5.30 \\
\hline 14 & Dewan Salman Fibre Ltd. & 4.12 & 5.18 & 5.35 & 6.62 & 6.19 & 9.09 \\
\hline 15 & Sui Nor. Gas Pipeline Ltd. & 4.10 & 4.13 & 4.17 & 2.95 & 3.95 & 3.91 \\
\hline 16 & Pakistan Cement Co. Ltd. & 4.03 & -1.91 & -2.91 & 0.57 & 1.17 & 1.18 \\
\hline 17 & Pak Telecom Corp. Ltd. & 3.97 & 4.40 & 5.31 & 7.01 & 6.65 & 6.55 \\
\hline 18 & Maple Leaf Cement Fact. Ltd. & 3.84 & 9.93 & 9.97 & 10.27 & 6.50 & 9.26 \\
\hline 19 & Faysal Bank Ltd. & 3.70 & 6.92 & 7.14 & 6.53 & 9.14 & 5.26 \\
\hline 20 & Sui Southern Gas Co. Ltd. & 3.44 & 3.34 & 3.11 & 2.99 & 3.33 & 3.53 \\
\hline 21 & Bank Alfalah Ltd. & 3.17 & 2.96 & 3.53 & 6.31 & 6.80 & 3.87 \\
\hline 22 & Karachi Elect. Corpl Ltd. & 2.36 & 6.40 & 5.81 & 1.80 & -1.41 & -0.10 \\
\hline 23 & PIA Corp (A) & 0.81 & -0.45 & 0.27 & 2.05 & 2.57 & 3.24 \\
\hline 24 & Bosicor Pakistan Ltd. & 0.39 & 8.81 & 9.26 & -9.12 & 0.65 & 5.14 \\
\hline 25 & PICIC Bank Ltd/NIB Bank & 0.14 & 3.49 & 9.79 & 10.85 & 6.46 & 3.85 \\
\hline
\end{tabular}

* Data is not publicly available due to non-listing status of the company in this year. 